\title{
Alternative mitochondrial functions in cell physiopathology: beyond ATP production
}

\section{A.J. Kowaltowski}

Departamento de Patologia Clínica, Faculdade de Ciências M édicas, Universidade Estadual de Campinas, Campinas, SP, Brasil

\section{Correspondence \\ A.J. Kowaltowski \\ Caixa Postal 6043 \\ Universidade Estadual de Campinas \\ 13083-970 Campinas, SP \\ Brasil \\ Fax: + 55-19-788-1118 \\ Present address: \\ Department of Biochemistry and \\ Molecular Biology, O regon Graduate \\ Institute of Science and Technology, \\ Beaverton, OR 97006-8921, USA. \\ E-mail: alicia@bmb.ogi.edu}

Publication supported by FAPESP.

$\ldots \ldots \ldots \ldots \ldots \ldots$

Received O ctober 7, 1999

Accepted November 4, 1999

\section{Abstract}

It is well known that mitochondria are the main site for ATP generation within most tissues. However, mitochondria also participate in a surprising number of alternative activities, including intracellular $\mathrm{Ca}^{2+}$ regulation, thermogenesis and the control of apoptosis. In addition, mitochondria are the main cellular generators of reactive oxygen species, and may trigger necrotic cell death under conditions of oxidative stress. This review concentrates on these alternative mitochondrial functions, and their role in cell physiopathology.

Key words

- Mitochondrial permeability transition

- Uncoupling proteins

- Alternative oxidase

- Cardioprotection

- Free radicals

- Aging

\section{Introduction}

In order to continuously generate ATP, mitochondria remove electrons from reduced substrates and transfer them to oxygen through a specialized group of respiratory complexes. According to Peter Mitchell's findings (1), the energy generated in this process is used to move protons from the mitochondrial matrix to the mitochondrial intermembrane space in a process known as proton pumping. Since the inner mitochondrial membrane is normally highly impermeable to protons, respiratory chain-generated proton pumping produces a proton potential across the inner mitochondrial membrane, which is used by the mitochondrial ATP synthase to generate ATP from ADP plus inorganic phosphate. ATP is thus produced in a highly conservative fashion, a process essential for cell physiology.

Although ATP synthesis is the primary role of mitochondria, it is not the only func- tion of these organelles. Indeed, many studies have shown that mitochondria present a surprising diversity of activities within the cell. This is compatible with the recent finding that mitochondria may have originated at essentially the same time as the nuclear component of the eukaryotic cell rather than in a separate, subsequent event (2). This review focuses on four of the main alternative mitochondrial functions and recent findings about them. The mitochondrial activities discussed here include heat generation, intracellular $\mathrm{Ca}^{2+}$ regulation, reactive oxygen species generation and the triggering of cell death.

\section{Thermogenesis}

Newborn, cold adapted and hibernating mammals have the ability to maintain their body temperature in a manner independent of shivering, but secondary to an adrenergically stimulated increase in respiration (3). Adrenergic stimuli in these animals promote 
a remarkable increase in blood flow to brown adipose tissue, which is the main tissue responsible for non-shivering thermogenesis (4). Interestingly, mitochondria within brown adipose tissue cells behave rather differently from those in other tissues: ATP synthesis is limited, the membrane potential is reduced and respiratory rates are increased $(5,6)$. This suggests that these mitochondria have inner membranes with a higher permeability to protons. In fact, brown adipose tissue mitochondria contain the uncoupling protein-1 (UcP1), a 32-kDa inner membrane protein which stimulates proton conductance (7). Ironically, UcP1 itself, when isolated and incorporated into liposomes, does not transport protons. Rather, it is an anion transporter, and promotes mitochondrial uncoupling by transporting fatty acid anions across the inner mitochondrial membrane in a manner regulated by purine nucleotides $(8,9)$. These fatty acids then protonate and flipflop electroneutrally across the lipid phase of the inner mitochondrial membrane, leading to increased mitochondrial proton permeability (see Scheme 1). As a consequence of this increased inner mitochondrial permeability to protons, part of the energy stored as membrane potential generated by the mitochondrial respiratory chain is released in the form of heat, when protons return to the mitochondrial matrix.

UcP1 was discovered in the 1970s, and was thought to be the only protein of this kind for over 20 years, until Vercesi and coworkers (10) described the existence of an uncoupling protein in mitochondria isolated from potato tubers, and later in a variety of other plant mitochondria (11). This uncou- pling protein, known as plant uncoupling mitochondrial protein (PUMP) functions similarly to UcP1 (12), and is involved in the heat generation necessary for fruit ripening (13).

Interestingly, in addition to PUMP, plant mitochondria may also contain the alternative oxidase, a mitochondrial respiratory pathway from ubiquinol to oxygen which does not promote proton pumping, and is, therefore, dissipative (14; see Scheme 1). The mitochondrial alternative oxidase is involved in the heat generation of thermogenic plants such as the skunk cabbage, and can be inhibited by salicylhydroxamic acid (14). The presence of two dissipative pathways in plants is curious, and raises questions regarding the regulation of these pathways. Although the contribution of each pathway under different conditions of plant thermogenesis has not been well established, it now seems clear that these pathways do not operate simultaneously (15).

Following the characterization of PUMP, three sequences corresponding to mammalian mitochondrial proteins homologous to UcP1 were found to be expressed (in quantities much lower than UcP1) ubiquitously (UcP2; 16) in skeletal muscle (UcP3; 17,18) or in the brain (UcP4; 19). Recent studies have determined that UcP2 and UcP3 are capable of translocating fatty acids, confirming that they are uncoupling proteins (20). The exact relevance of these newly characterized mammalian uncoupling proteins is still not completely clear, but some interesting studies suggest that they may be involved in the control of body weight. In this sense, it has been shown that UcP3 gene promoted by the plant mitc alternative oxidase (alt. a dissipating process which may not generate a proton gradient. The proton gradient is decreased by the activity of uncoupling proteins (UcP), which translocate fatty acid anions from the mitochondrial matrix to the cytoplasmic surface of the inner mitochondrial membrane. Fatty acid anions then combine with protons, and flip-flop electroneutrally across the lipid bilayer.

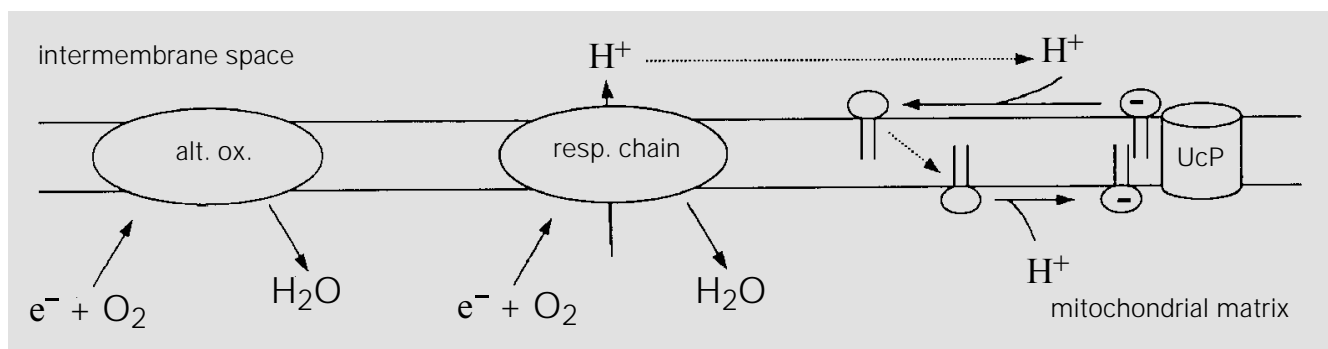


expression is stimulated by a high-fat diet (21), and reduced by dietary restriction $(22,23)$. Reduced UcP3 expression is also linked to obesity-related non-insulin dependent diabetes (24). The relationship between $\mathrm{UcP} 2$ and body weight is suggested by the demonstration that leptin, which reduces body weight by decreasing food intake and increasing thermogenesis, induces $\mathrm{UcP} 2$ gene expression (25).

\section{Regulation of intracellular $\mathrm{Ca}^{2+}$ homeostasis}

Cytosolic $\mathrm{Ca}^{2+}$ levels are maintained at concentrations approximately 10,000 times lower than the $\mathrm{Ca}^{2+}$ concentrations in the extracellular medium (for review, see 26,27). This process is controlled mainly by plasma membrane and endoplasmic reticulum $\mathrm{Ca}^{2+}$ ATPases and by $\mathrm{Ca}^{2+}$ exchanges in a process that requires energy. Clearly, if mitochondria become dysfunctional and ATP synthesis is impaired, cellular $\mathrm{Ca}^{2+}$ homeostasis will be affected.

In addition to providing the energy necessary for intracellular $\mathrm{Ca}^{2+}$ regulation, mitochondria themselves participate in the control of intracellular $\mathrm{Ca}^{2+}$ concentrations. In the presence of a membrane potential, cat- ions can be accumulated in mitochondria down the membrane potential, as long as there is a transport pathway. Thus, mitochondria from vertebrates are capable of actively accumulating $\mathrm{Ca}^{2+}$ ions, since they possess a $\mathrm{Ca}^{2+}$ uniporter (for review, see 26,27).

$\mathrm{Ca}^{2+}$ uptake by mitochondria depends on the presence of a membrane potential which provides the driving force for accumulation (the negative intramitochondrial charge; see Scheme 2), and is inhibited by submicromolar concentrations of ruthenium red, an inhibitor of the $\mathrm{Ca}^{2+}$ uniporter $(26,27)$. Ruthenium red also inhibits a second mechanism for $\mathrm{Ca}^{2+}$ uptake into mitochondria through the rapid $\mathrm{Ca}^{2+}$ uptake mode (RaM;28), although 10 times higher concentrations are required. The channel which promotes $\mathrm{RaM} \mathrm{Ca}{ }^{2+}$ uptake has not been characterized, and may be the $\mathrm{Ca}^{2+}$ uniporter itself, operating under a more rapid conductivity mode. However, the distinct sensitivity of RaM to inhibitors of the $\mathrm{Ca}^{2+}$ uniporter and mainly the lack of sensitivity to $\mathrm{Mg}^{2+}$, which inhibits $\mathrm{Ca}^{2+}$ uptake via the $\mathrm{Ca}^{2+}$ uniporter (28), suggest that RaM may involve an independent channel.

The total $\mathrm{Ca}^{2+}$ accumulation capacity of mitochondria can be quite high, as long as inorganic phosphate is accumulated in par-

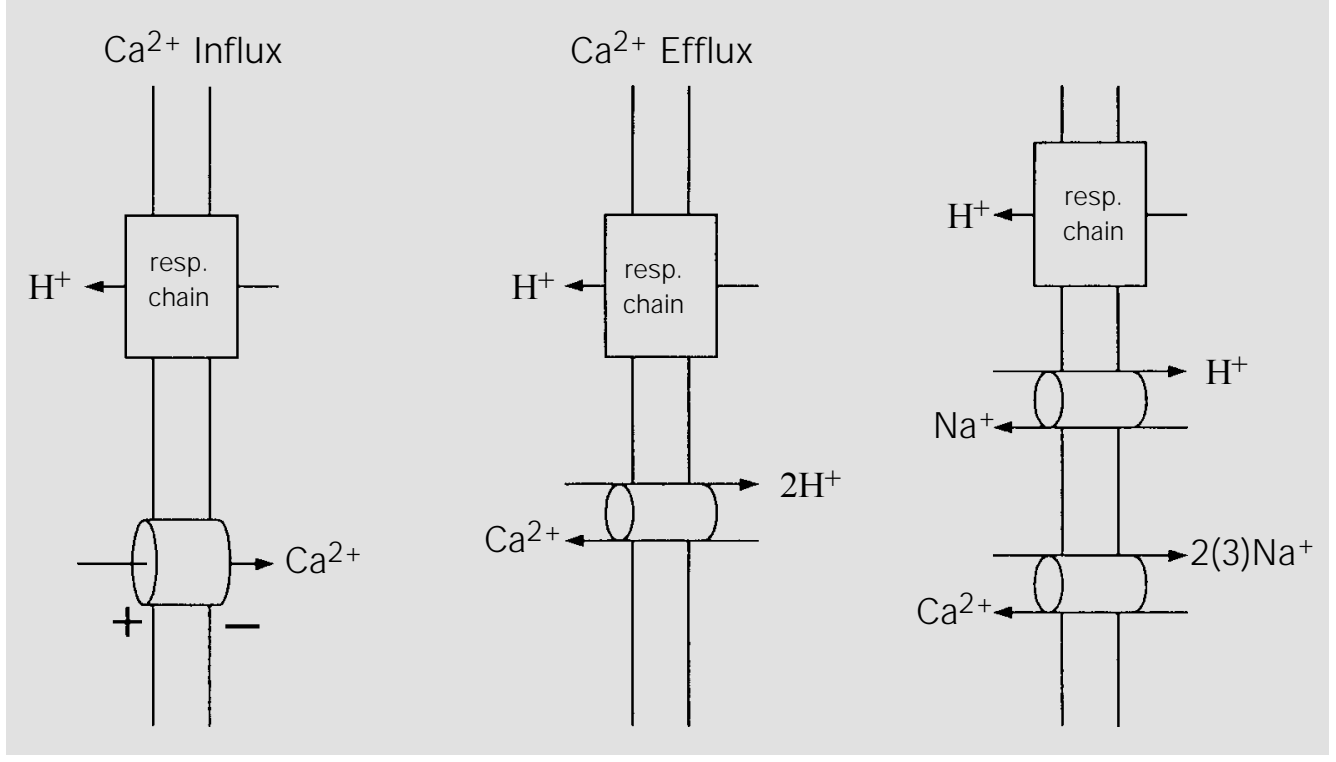

Scheme 2 - Mitochondrial $\mathrm{Ca}^{2+}$ transport. Mitochondrial $\mathrm{Ca}^{2+}$ influx is mediated by the inner membrane uniporter or RaM and driven by the proton electrochemical potential. $\mathrm{Ca}^{2+}$ efflux is promoted by the $\mathrm{Ca}^{2+} / 2 \mathrm{H}^{+}$ and $\mathrm{Ca}^{2+} / 2 \mathrm{Na}^{+}$(or $\mathrm{Ca}^{2+} / 3 \mathrm{Na}^{+}$) exchange. $\mathrm{Na}^{+}$redistribution is maintained by the $\mathrm{Na}^{+} / \mathrm{H}^{+}$antiporter. resp. chain, Respiratory chain. 
allel, to compensate for changes in the mitochondrial $\mathrm{pH}$ gradient across the inner mitochondrial membrane, and the inner membrane is not permeabilized by the mitochondrial permeability transition (MPT) (see discussion below). Although accumulation capacity is high, the affinity for mitochondrial $\mathrm{Ca}^{2+}$ uptake is low, requiring extramitochondrial $\mathrm{Ca}^{2+}$ concentrations of at least 200-300 $\mathrm{nM}(26,27)$. Because of this low affinity of the mitochondrial $\mathrm{Ca}^{2+}$ uptake and the typical cytosolic free $\mathrm{Ca}^{2+}$ concentrations under resting conditions $(<100 \mathrm{nM})$, mitochondrial $\mathrm{Ca}^{2+}$ uptake was believed not to occur inside the cell under physiological conditions. This hypothesis has now been overruled by observations of $\mathrm{Ca}^{2+}$ uptake into mitochondria within intact cells (29-31). It is possible that mitochondria take up $\mathrm{Ca}^{2+}$ during periodic increases in intracellular $\mathrm{Ca}^{2+}$ concentrations $\left(\mathrm{Ca}^{2+}\right.$ spikes; 29$)$, or through a close interaction with the endoplasmic reticulum $\mathrm{Ca}^{2+}$ release pathways (30) and plasma membrane channels (32).

Confirming that $\mathrm{Ca}^{2+}$ uptake by mitochondria is important for cell function, mitochondria have developed an elaborate $\mathrm{Ca}^{2+}$ release system composed of two transporters: the $\mathrm{Ca}^{2+} / 2 \mathrm{H}^{+}$exchange, and the $\mathrm{Ca}^{2+}$ / $2 \mathrm{Na}^{+}\left(\right.$or $\left.\mathrm{Ca}^{2+} / 3 \mathrm{Na}^{+} ; 33\right)$ exchange. As shown in Scheme $2, \mathrm{Ca}^{2+}$ efflux is energetically uphill, and thus dissipates the mitochondrial proton gradient. $\mathrm{Ca}^{2+}$ efflux through these carriers is 500-1000 times slower than $\mathrm{Ca}^{2+}$ uptake through the uniporter, and can be inhibited by respiratory inhibitors and uncouplers $\left(\mathrm{Ca}^{2+} / 2 \mathrm{H}^{+}\right.$exchange) or diltiazem, verapamil, clonazepam, amiodarone, $\mathrm{Mg}^{2+}$ and tetraphenylphosphonium $\left(\mathrm{Ca}^{2+} / 2 \mathrm{Na}^{+}\right.$ exchange; for reviews, see 26,27).

The physiological role of $\mathrm{Ca}^{2+}$ may be related to the regulation of respiratory activity. The presence of $\mathrm{Ca}^{2+}$ in the mitochondrial matrix stimulates respiration by affecting three mitochondrial enzymes: pyruvate dehydrogenase phosphatase, $\mathrm{NAD}^{+}$-linked isocitrate dehydrogenase and 2-oxoglutarate dehydrogenase. This enzymatic activation justifies the enhanced citric acid cycle activity and respiratory rates observed in tissues upon adrenergic stimulation, which leads to elevated intracellular $\mathrm{Ca}^{2+}$ concentrations (34).

Although the presence of approximately $1 \mu \mathrm{M} \mathrm{Ca}^{2+}$ in the mitochondrial matrix has the beneficial effect of stimulating respiratory activity, intramitochondrial $\mathrm{Ca}^{2+}$ must be carefully regulated within the cell, since excessive mitochondrial $\mathrm{Ca}^{2+}$ accumulation may lead to a nonselective inner membrane permeabilization, known as mitochondrial permeability transition (MPT; see 35-37). MPT is a $\mathrm{Ca}^{2+}$-triggered permeabilization of the inner mitochondrial membrane to protons, ions and solutes of up to $1500 \mathrm{kDa}$. In isolated mitochondria, the $\mathrm{Ca}^{2+}$ quantities necessary for MPT triggering vary widely with distinct experimental conditions and from one tissue to another. MPT is thus more likely to occur (or occurs in the presence of smaller $\mathrm{Ca}^{2+}$ loads) in the presence of MPT inducers such as inorganic phosphate, pyridine nucleotide oxidants and dithiol reagents. On the other hand, $\mathrm{ADP}, \mathrm{Mg}^{2+}$, antioxidants and cyclosporin A (known as a specific MPT inhibitor) prevent MPT. In vitro, mitochondrial membrane permeabilization secondary to MPT results in a cyclosporin-A sensitive drop in mitochondrial membrane potential, and the release of $\mathrm{Ca}^{2+}$ accumulated previously, a process reversible through $\mathrm{Ca}^{2+}$ chelation within a few minutes after its onset. In isotonic media, MPT also results in colloidosmotic swelling of isolated mitochondria due to the high protein content of the mitochondrial matrix. Undoubtedly, MPT occurring under these conditions results in irreversible mitochondrial dysfunction (see further discussion under "Triggering cell death"). However, the characteristics of MPT under distinct experimental conditions are very variable, and a more selective $(<300$ $\mathrm{kDa})$ "low-conductance" mode of the permeability transition has been observed (for 
review, see 38). According to the model devised by Ichas and Mazat (38), the low conductance mode of MPT does not involve mitochondrial swelling, is fully reversible upon matrix acidification secondary to the mitochondrial permeabilization to protons, and may be a mechanism through which $\mathrm{Ca}^{2+}$ is quickly released from the mitochondrial matrix. In the intact cell, low-conductance MPT pores may participate in the regulation of cytoplasmic $\mathrm{Ca}^{2+}$ signals $(38,39)$.

\section{Reactive oxygen species (RO S) generation}

As a by-product of electron transport, a small amount of molecular oxygen $\left(\mathrm{O}_{2}\right)$ undergoes monoelectronic reduction at intermediate steps of the mitochondrial respiratory chain, resulting in the generation of the superoxide radical $\left(\mathrm{O}_{2}^{-\bullet}\right)$. This small but continuous "electron leak" makes mitochondria the main generation site for reactive oxygen species within most cells. Catalyzed by intramitochondrial superoxide dismutase, $\mathrm{O}_{2}^{-\bullet}$ may form hydrogen peroxide $\left(\mathrm{H}_{2} \mathrm{O}_{2}\right)$, and subsequently hydroxyl radicals $\left(\mathrm{OH}^{\bullet}\right.$ formed through the $\mathrm{Fe}^{2+}$-dependent Fenton's reaction) and other ROS (see Scheme 3 and Refs. 37,40).

Normally, respiratory-chain generated ROS are detoxified by the efficient mitochondrial antioxidant systems (see Scheme 3 and Ref. 40 for review), and do not cause any permanent damage to mitochondria. However, under nonphysiological conditions, or over time, mitochondrially generated ROS may lead to both mitochondrial and cellular damage. As an example, $\mathrm{Ca}^{2+}$ triggered MPT, which is an early step in some conditions leading to cell death, is a result of mitochondrial oxidative stress (for reviews, see 37,40). Also, glutamate neurotoxicity mediated by excessive stimulation of $\mathrm{N}$-methyl-D-aspartate receptors occurs secondarily to excessive mitochondrial $\mathrm{Ca}^{2+}$ uptake and oxidative stress (41). Finally, many important results of mitochondrial oxidative stress may be observed during aging, when damage to mitochondrial DNA accumulates over time, and may result in alterations in the synthesis of components of the respiratory chain (42).

Monoelectronic reduction of oxygen resulting in mitochondrial ROS generation occurs mainly at the level of complexes I and III of the respiratory chain, most probably by donation of an electron from intermediately reduced forms of ubiquinones (43). Since complex IV is not an important site for $\mathrm{O}_{2}^{-\bullet}$ generation, mitochondria must not necessarily respire to generate ROS. In fact, certain respiratory inhibitors such as antimycin A may increase mitochondrial ROS generation as they lead to an accumulation of intermediately reduced ubiquinones. Other conditions that favor mitochondrial ROS generation are high membrane potentials, hyperoxia, ex-

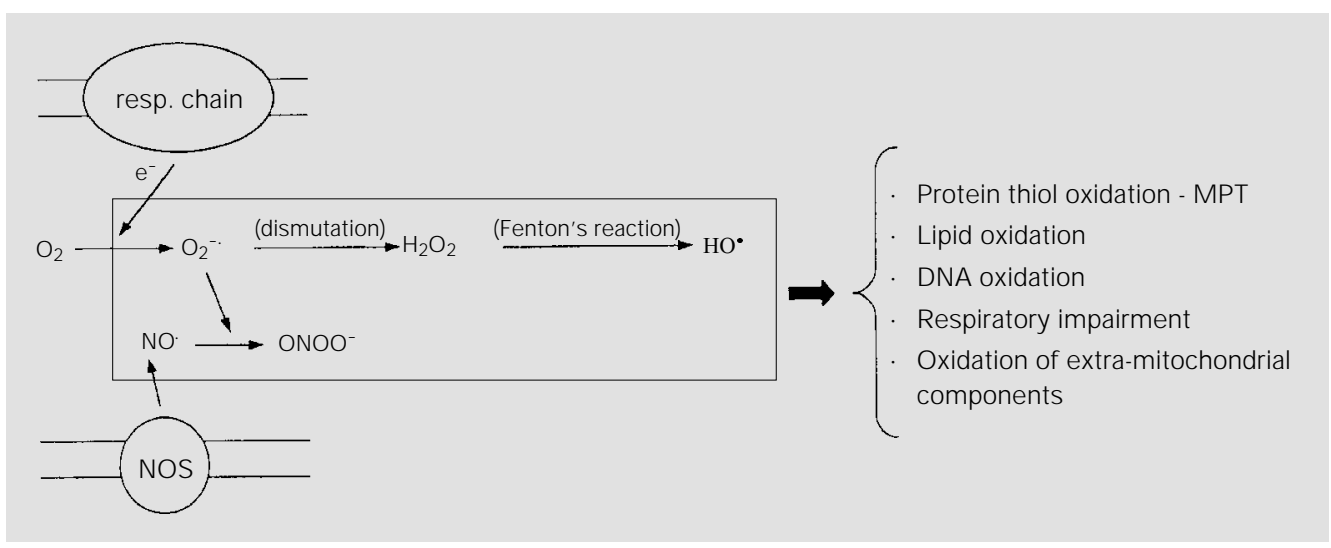

Scheme 3 - Mitochondrial generation of ROS. The respiratory chain (resp. chain) produces superoxide radicals $\left(\mathrm{O}_{2}^{--}\right)$, which generate hydrogen peroxide $\left(\mathrm{H}_{2} \mathrm{O}_{2}\right)$ and hydroxyl radicals (HO'). Mitochondrial nitric oxide synthase (NOS) produces nitric oxide (NO), which combines with $\mathrm{O}_{2}^{--}$to generate peroxinitrite $\left(\mathrm{ONOO}^{-}\right)$. All these ROS may cause mitochondrial and cellular damage if present in excess. MPT, Mitochondrial permeability transition. 
cessive $\mathrm{Ca}^{2+}$ uptake and anoxia/reoxygenation (for review, see 40). Both increased cytosolic $\mathrm{Ca}^{2+}$ levels and anoxia/reoxygenation of mitochondria occur under conditions of ischemia/reperfusion in vivo. Indeed, reperfusion injury has been closely associated with mitochondrial oxidative stress and MPT $(44,45)$.

In addition to producing $\mathrm{O}_{2}^{-\bullet}$ through electron leakage in the respiratory chain, mitochondria also produce nitric oxide $\left(\mathrm{NO}^{\bullet}\right)$ through the activity of a constitutive nitric oxide synthase similar to the inducible cellular nitric oxide synthase. $\mathrm{NO} \bullet$ levels regulate mitochondrial respiratory activity, but it is not yet known if this is the principal function of mitochondrial $\mathrm{NO}^{\bullet}(46)$.

\section{Triggering cell death}

Not surprisingly, mitochondrial dysfunction and consequent cellular ATP depletion can result in cell death. Indeed, necrotic cell death under conditions such as ischemia/ reperfusion is strongly inhibited by preventing associated mitochondrial alterations, suggesting that mitochondrial dysfunction is the primary trigger for cell death under these conditions $(44,45,47)$. Mitochondrial dysfunctions which may potentially lead to necrosis include MPT, respiratory inhibition, uncoupling between respiration and oxidative phosphorylation, and excessive ROS generation. Excessive ROS generation by mitochondria may contribute to necrotic cell death even if cellular ATP is maintained by affecting intracellular $\mathrm{Ca}^{2+}$ homeostasis (41).

However, mitochondrially triggered cell death is not always necrotic. Recent evidence has identified these organelles as regulators of the highly complex process of energy dependent apoptotic cell death (see Scheme 4). Two mitochondrial intermembrane-space proteins, cytochrome $c$ and the apoptosis inducing factor (AIF), have been shown to migrate from a mitochondrial to a cytosolic location shortly before hallmarks of apoptosis are observed $(48,49)$. Also, microinjection of both proteins into healthy cells results in the induction of apoptosis $(50,51)$. In addition to cytochrome $c$ and AIF, mitochondria contain pro-caspase 9, pro-caspase 3 and pro-caspase $2(52,53)$ which, when released into the cytosol and
Scheme 4 - Mitochondria can trigger cell death. Intact mitochondria contain cytochrome $\mathrm{c}$ (circles) and the apoptosis inducing factor (AIF, lines) in the intermembrane space. AlF is released from mitochondria after the latter undergo nonselective inner membrane permeabilization secondary to MPT, which results in mitochondrial swelling and outer membrane disruption. Cytochrome c may be released into the cytosol after MPT, upon Bax targeting to mitochondria or treatment with $\mathrm{Ca}^{2+}$. Once in the cytosol, both cytochrome c and AIF trigger apoptosis. MPT may also promote necrosis, since it results in mitochondrial dysfunction. MPT, Mitochondrial permeability transition.

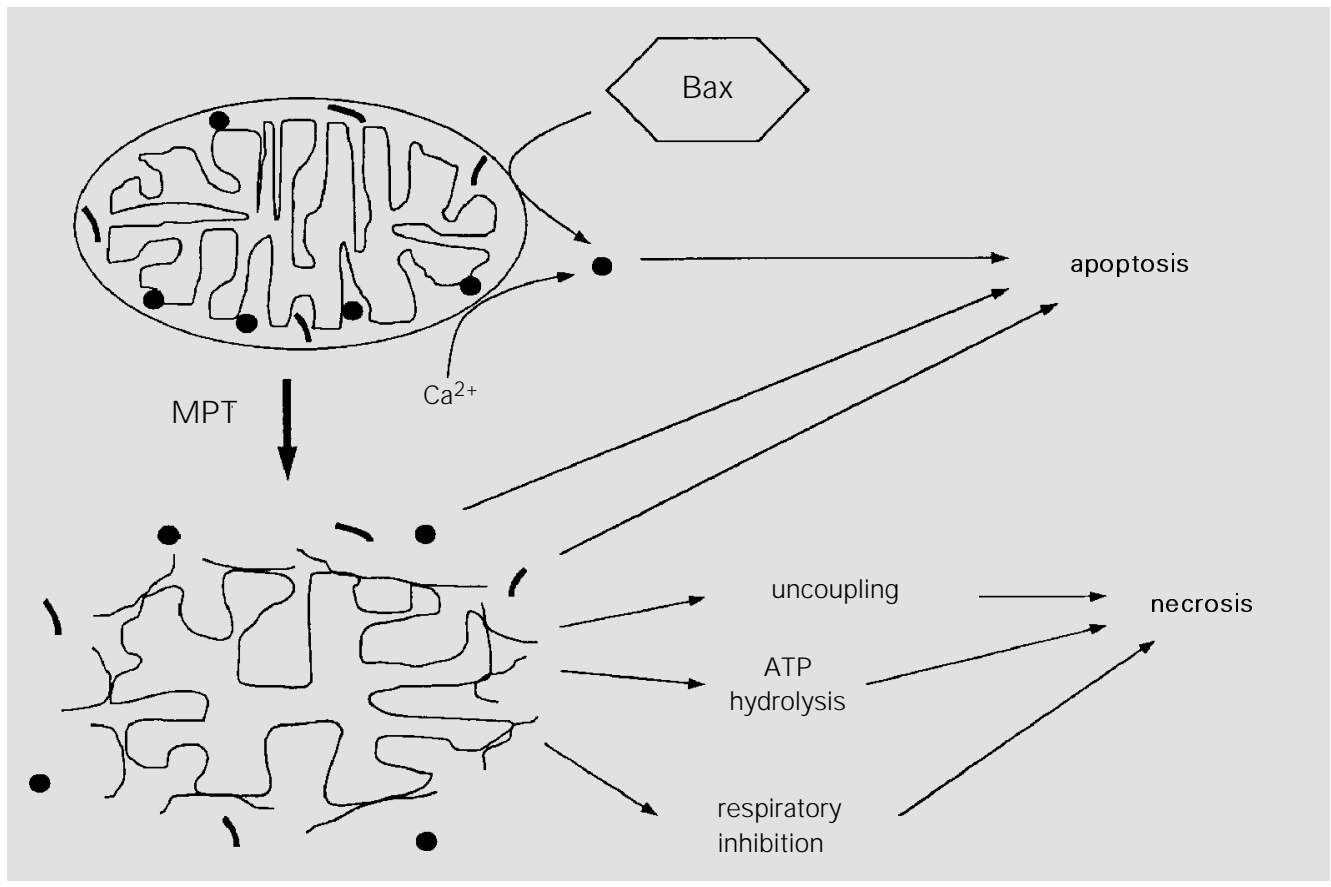


cleaved, act as aspartate-specific proteases that initiate the apoptotic cascade.

Further evidence that mitochondria participate in apoptosis is provided by the location of Bcl-2 family proteins within the cell. $b c l-2$ was originally identified as a gene related to oncogenesis in B-cell lymphocytes, and later found to express a protein (Bcl-2) which is part of a family of proteins presenting both anti- and pro-apoptotic activities. Bcl-2 itself is predominantly located on the outer mitochondrial membrane, and its main antiapoptotic effect seems to be the inhibition of mitochondrial cytochrome $c$ and AIF release $(48,49)$. On the other hand, pro-apoptotic Bcl-2 family proteins such as Bax and Bid are primarily cytosolic, and upon apoptotic stimuli assume a mitochondrial location, an event which coincides with the release of mitochondrial cytochrome $c$ $(54,55)$.

Although the latest evidence has been almost unanimous in showing that mitochondria have an important role in the control of apoptosis, the exact mechanisms by which mitochondria promote this regulation are not yet fully understood. As an example, it seems clear that the occurrence of MPT in vitro promotes the release of mitochondrial cytochrome $c$, but it is still controversial if this is the primary mechanism of cytochrome $c$ release within cells. Also, the mechanism by which Bcl-2 family proteins interact with mitochondria and promote or prevent the release of cytochrome $c$ has not been well established. These and other still unresolved points of interest should be further investigated within the next few years.

In agreement with studies showing a role for mitochondria in the initial steps of both necrosis and apoptosis, mitochondrially active drugs have been shown to be cardioprotective. Of great interest in this line of study is the evidence that openers of the mitochondrial (but not plasma membrane) ATP-inhibited $\mathrm{K}^{+}$channels, such as diazoxide, present cardioprotective effects. In addition, 5-
$\mathrm{OH}$ decanoate, a specific mitochondrial $\mathrm{K}^{+}$ channel inhibitor, prevents ischemic preconditioning and the cardioprotective effects of $\mathrm{K}^{+}$channel openers (56). These interesting experiments show that the increased flux of $\mathrm{K}^{+}$into mitochondria through the ATP-sensitive $\mathrm{K}^{+}$channel is cytoprotective. Since the primary effect of $\mathrm{K}^{+}$influx is to promote a small increase in mitochondrial volume (which does not result in outer mitochondrial membrane rupture), cardioprotection promoted by diazoxide may be the result of increased $B$ oxidation of fatty acids and respiratory activity secondary to increased mitochondrial volume (57).

Inhibitors of the mitochondrial permeability transition are also cytoprotective in various in vivo and in vitro cell death models $(44,45,47)$. It is believed that these conditions lead to intracellular $\mathrm{Ca}^{2+}$ increases, with excessive mitochondrial $\mathrm{Ca}^{2+}$ uptake, oxidative stress and MPT. Preventing MPT avoids ATP depletion secondary to mitochondrial dysfunction, and protects from necrotic cell death under these conditions.

\section{Final remarks}

As summarized here, mitochondria present a variety of important functions in addition to producing ATP. As an example, mitochondria present regulated pathways that promote energy dissipation, such as the mitochondrial uncoupling proteins and the alternative oxidase, which seem to present the main function of promoting nonshivering thermogenesis. Thermogenesis is ultimately achieved when the chemical energy contained in reduced substrates is released, but not explored for ATP synthesis.

It is also well established that mitochondria actively take up $\mathrm{Ca}^{2+}$ within intact cells, and that this $\mathrm{Ca}^{2+}$ uptake may both regulate mitochondrial respiratory parameters and influence cytosolic $\mathrm{Ca}^{2+}$ transients. Mitochondrial $\mathrm{Ca}^{2+}$ uptake occurs through the $\mathrm{Ca}^{2+}$ uniporter or $\mathrm{RaM}$, while $\mathrm{Ca}^{2+}$ release 
occurs through exchange with $\mathrm{Na}^{+}$and $\mathrm{H}^{+}$ or, eventually, the low-conductance MPT pore.

In addition, mitochondria constantly produce ROS, and have thus developed an efficient antioxidant system. However, imbalances in ROS generation or detoxification systems may result in a condition of oxidative stress. Under these conditions, damage to both mitochondrial and cellular constituents may occur. Functional mitochondrial impairment leading to cellular ATP depletion is an initial step in many models for necrotic cell death. Mitochondria may also trigger ATP-dependent apoptotic cell death through the release of pro-apoptotic proteins from the mitochondrial intermembrane space into the cytosol. These findings agree with the characterization of the cytoprotective ef- fects of mitochondrially active drugs (44, 45,47).

Thus, alternative mitochondrial activities, in addition to ATP synthesis, are important factors in cell physiology, and may tip the balance between cell survival and death. Further knowledge about these alternative mitochondrial activities will contribute to the development of more efficient mitochondrially targeted drugs capable of better preventing ischemic injury. The modulation of mitochondrial activities may also be effective in the treatment of obesity and diabetes.

\section{Acknowledgments}

The author wishes to thank Dr. R.F. Castilho for a critical reading of the manuscript.

\section{References}

1. Mitchell P \& Moyle J (1965). Stoichiometry of proton translocation through the respiratory chain and adenosine triphosphatase systems of rat liver mitochondria. Nature, 208: 147-151.

2. Gray MW, Burger G \& Lang BF (1999). Mitochondrial evolution. Science, 283: 1476-1481.

3. Nicholls DG \& Locke RM (1984). Thermogenic mechanisms in brown fat. Physiological Reviews, 64: 1-64.

4. Foster DO \& Frydman ML (1978). Brown adipose tissue: the dominant site of nonshivering thermogenesis in the rat. Experientia Supplementum, 32: 147-151.

5. Smith RE, Roberts JC \& Hittelman KJ (1966). Nonphosphorylating respiration of mitochondria from brown adipose tissue of rats. Science, 154: 653-654.

6. Nicholls DG (1976). The bioenergetics of brown adipose tissue mitochondria. FEBS Letters, 61: 103-110.

7. Nicholls DG, Bernson VS \& Heaton GM (1978). The identification of the component in the inner membrane of brown adipose tissue mitochondria responsible for regulating energy dissipation. Experientia Supplementum, 32: 89-93.

8. J ežek P, Orosz DE, Modriansky M \& Garlid KD (1994). Transport of anions and protons by the mitochondrial uncoupling pro- tein and its regulation by nucleotides and fatty acids. A new look at old hypotheses. J ournal of Biological Chemistry, 269: 26184-26190.

9. Garlid KD, Orosz DE, Modriansky M, Vassanelli S \& J ežek P (1996). On the mechanism of fatty acid-induced proton transport by mitochondrial uncoupling protein. J ournal of Biological Chemistry, 271: 2615-2620.

10. Vercesi $A E$, Martins IS, Silva MAP, Leite HMF, Cuccovia IM \& Chaimovich H (1995). PUM Ping plants. Nature, 375: 24.

11. J ežek $P$, Engstova $H$, Zackova $M$, Vercesi $A E$, Costa $A D$, Arruda $P \&$ Garlid $K D$ (1998). Fatty acid cycling mechanism and mitochondrial uncoupling proteins. Biochimica et Biophysica Acta, 1365: 319327.

12. J ežek P, Costa AD \& Vercesi AE (1997). Reconstituted plant uncoupling mitochondrial protein allows for proton translocation via fatty acid cycling mechanism. J ournal of Biological Chemistry, 272: 24272-24278.

13. Almeida AM, J armuszkiewicz W, Khomsi H, Arruda P, Vercesi AE \& Sluse FE (1999). Cyanide-resistant, ATP-synthesis-sustained, and uncoupling-protein-sustained respiration during postharvest ripening of tomato fruit. Plant Physiology, 119: 1323-
1330.

14. Moore AL \& Siedow J N (1991). The regulation and nature of the cyanide-resistant alternative oxidase of plant mitochondria. Biochimica et Biophysica Acta, 1059: 121140.

15. Sluse FE, Almeida AM, J armuszkiewicz W \& Vercesi AE (1998). Free fatty acids regulate the uncoupling protein and alternative oxidase activities in plant mitochondria. FEBS Letters, 433: 237-240.

16. Fleury $C$, Neverova $M$, Collins $S$, Raimbault S, Champigny O, LeviMeyrueis C, Bouillaud F, Seldin MF, Surwit RS, Ricquier $\mathrm{D} \&$ Warden $\mathrm{CH}$ (1997). Uncoupling protein-2: a novel gene linked to obesity and hyperinsulinemia. Nature Genetics, 15: 269-272.

17. Boss O, Samec S, Paoloni-Giacobino A, Rossier C, Dulloo A, Seydoux J , Muzzin P \& Giacobino JP (1997). Uncoupling protein-3: a new member of the mitochondrial carrier family with tissue-specific expression. FEBS Letters, 408: 39-42.

18. Vidal-Puig A, Solanes G, Grujic D, Flier J S \& Lowell BB (1997). UCP3: an uncoupling protein homologue expressed preferentially and abundantly in skeletal muscle and brown adipose tissue. Biochemical and Biophysical Research Communications, 235: 79-82. 
19. Mao W, Yu XX, Zhong A, Li W, Brush J, Sherwood SW, Adams SH \& Pan G (1999). UCP4, a novel brain-specific mitochondrial protein that reduces membrane potential in mammalian cells. FEBS Letters, 443: 326-330.

20. J abưrek $M$, Varecha $M$, Gimeno $R E$, Dembski $M$, J ežek $P$, Zhang $M$, Burn $P$, Tartaglia LA \& Garlid KD (1999). Transport function and regulation of mitochondrial uncoupling proteins 2 and 3 . J ournal of Biological Chemistry, 274: 26003-26007.

21. Brun S, Carmona MC, Mampel T, Vinas $O$, Giralt $M$, Iglesias $R$ \& Villarroya $F$ (1999). Uncoupling protein-3 gene expression in skeletal muscle during development is regulated by nutritional factors that alter circulating non-esterified fatty acids. FEBS Letters, 453: 205-209.

22. Millet $L$, Vidal $H$, Larrouy $D$, Andreelli $F$, Laville M \& Langin D (1998). mRNA expression of the long and short forms of uncoupling protein-3 in obese and lean humans. Diabetologia, 41: 829-832.

23. Esterbauer $\mathrm{H}$, Oberkofler $\mathrm{H}$, Dallinger $\mathrm{G}$, Breban D, Hell E, Krempler F \& Patsch W (1999). Uncoupling protein-3 gene expression: reduced skeletal muscle mRNA in obese humans during pronounced weight loss. Diabetologia, 42: 302-309.

24. KrookA, Digby J, O'Rahilly S, Zierath J R \& Wallberg-Henriksson H (1998). Uncoupling protein 3 is reduced in skeletal muscle of NIDDM patients. Diabetes, 47: 1528-1531.

25. Zhou YT, Shimabukuro M, Koyama K, Lee Y, Wang MY, Trieu F, Newgard CB \& Unger RH (1997). Induction by leptin of uncoupling protein-2 and enzymes of fatty acid oxidation. Proceedings of the $\mathrm{Na}$ tional Academy of Sciences, USA, 94: 6386-6390.

26. Gunter TE \& Pfeiffer DR (1990). Mechanisms by which mitochondria transport calcium. American J ournal of Physiology, 258: C755-C786.

27. Gunter KK \& Gunter TE (1994). Transport of calcium by mitochondria. J ournal of Bioenergetics and Biomembranes, 26: 471-485.

28. Gunter TE, Buntinas L, Sparagna GC \& Gunter KK (1998). The Ca ${ }^{2+}$ transport mechanisms of mitochondria and $\mathrm{Ca}^{2+}$ uptake from physiological-type $\mathrm{Ca}^{2+}$ transients. Biochimica et Biophysica Acta, 1366: 5-15.

29. Rizzuto R, Simpson AW, Brini M \& Pozzan $T$ (1992). Rapid changes of mitochondrial $\mathrm{Ca}^{2+}$ revealed by specifically targeted recombinant aequorin. Nature, 358: 325327.
30. Rizzuto $R$, Brini $M$, Murgia $M \&$ Pozzan $T$ (1993). Microdomains with high $\mathrm{Ca}^{2+}$ close to IP3-sensitive channels that are sensed by neighboring mitochondria. Science, 262: 744-747.

31. Bassani RA, Bassani JW \& Bers DM (1992). Mitochondrial and sarcolemmal $\mathrm{Ca}^{2+}$ transport reduce $\left[\mathrm{Ca}^{2+}\right] \mathrm{i}$ during caffeine contractures in rabbit cardiac myocytes. J ournal of Physiology, 453: 591608.

32. Peng TI \& Greenamyre J T (1998). Privileged access to mitochondria of calcium influx through $\mathrm{N}$-methyl-D-aspartate receptors. Molecular Pharmacology, 53: 974-980.

33. J ung DW, Baysal K \& Brierley GP (1995). The sodium-calcium antiport of heart mitochondria is not electroneutral. J ournal of Biological Chemistry, 270: 672-678.

34. Hansford RG (1994). Physiological role of mitochondrial $\mathrm{Ca}^{2+}$ transport. J ournal of Bioenergetics and Biomembranes, 26: 495-508.

35. Bernardi $P$ (1996). The permeability transition pore. Control points of a cyclosporin A-sensitive mitochondrial channel involved in cell death. Biochimica et Biophysica Acta, 1275: 5-9.

36. Halestrap AP, Connern CP, Griffiths EJ \& Kerr PM (1997). Cyclosporin A binding to mitochondrial cyclophilin inhibits the permeability transition pore and protects hearts from ischaemia/reperfusion injury. Molecular and Cellular Biochemistry, 174: 167-172.

37. Kowaltowski AJ \& Vercesi AE (1999). Mitochondrial damage induced by conditions of oxidative stress. Free Radicals in Biology and Medicine, 26: 463-471.

38. Ichas F \& Mazat J P (1998). From calcium signaling to cell death: two conformations for the mitochondrial permeability transition pore. Switching from low- to highconductance state. Biochimica et Biophysica Acta, 1366: 33-50.

39. Smaili SS \& Russell J T (1999). The permeability transition pore regulates both mitochondrial membrane potential and agonist-evoked $\mathrm{Ca}^{2+}$ signals in oligodendrocyte progenitors. Cell Calcium, 26 (in press).

40. Kowaltowski AJ \& Vercesi AE (2000). Reactive oxygen generation by mitochondria. In: Lemasters JJ \& Nieminem A-L (Editors), Mitochondria in Pathogenisis. Plenum Publishing Corporation, New York (in press).

41. Castilho RF, Ward MW \& Nicholls DG (1999). Oxidative stress, mitochondrial function, and acute glutamate excitotox- icity in cultured cerebellar granule cells. J ournal of Neurochemistry, 72: 13941401.

42. Wei YH, Lu CY, Lee HC, Pang CY \& Ma YS (1998). Oxidative damage and mutation to mitochondrial DNA and age-dependent decline of mitochondrial respiratory function. Annals of the New York Academy of Sciences, 854: 155-170.

43. Cadenas E, Boveris A, Ragan $\mathrm{Cl} \&$ Stoppani AO (1977). Production of superoxide radicals and hydrogen peroxide by $\mathrm{NADH}$-ubiquinone reductase and ubiquinol-cytochrome $c$ reductase from beefheart mitochondria. Archives of Biochemistry and Biophysics, 180: 248-257.

44. Griffiths EJ \& Halestrap AP (1993). Protection by Cyclosporin A of ischemia/reperfusion-induced damage in isolated rat hearts. J ournal of Molecular and Cellular Cardiology, 25: 1461-1469.

45. Griffiths EJ \& Halestrap AP (1995). Mitochondrial non-specific pores remain closed during cardiac ischaemia, but open upon reperfusion. Biochemical J ournal, 307: 93-98.

46. Giulivi C (1998). Functional implications of nitric oxide produced by mitochondria in mitochondrial metabolism. Biochemical J ournal, 332: 673-679.

47. Friberg $H$, Ferrand-Drake $M$, Bengtsson $F$, Halestrap AP \& Wieloch T (1998). Cyclosporin A, but not FK 506, protects mitochondria and neurons against hypoglycemic damage and implicates the mitochondrial permeability transition in cell death. J ournal of Neuroscience, 18: 5151-5159.

48. Green DR \& Reed J C (1998). Mitochondria and apoptosis. Science, 281: 13091312.

49. Susin SA, Zamzami $N \&$ Kroemer $G$ (1998). Mitochondria as regulators of apoptosis: doubt no more. Biochimica et Biophysica Acta, 1366: 151-165.

50. Zhivotovsky B, Orrenius S, Brustugun OT \& Doskeland SO (1998). Injected cytochrome c induces apoptosis. Nature, 391: 449-450.

51. Susin SA, Lorenzo HK, Zamzami N, Marzo I, Snow BE, Brothers GM, Mangion J, J acotot $E$, Costantini $P$, Loeffler $M$, Larochette N, Goodlett DR, Aebersold R, Siderovski DP, Penninger J M \& Kroemer $\mathrm{G}$ (1999). M olecular characterization of mitochondrial apoptosis-inducing factor. Nature, 397: 441-446.

52. Susin SA, Lorenzo HK, Zamzami N, Marzo I, Brenner C, Larochette N, Prevost MC, Alzari PM \& Kroemer G (1999). Mitochondrial release of caspase-2 and -9 during the apoptotic process. J ournal of Experi- 
mental Medicine, 189: 381-394.

53. Krajewski S, Krajewska M, Ellerby LM, Welsh K, Xie Z, Deveraux QL, Salvesen GS, Bredesen DE, Rosenthal RE, Fiskum G \& Reed J C (1999). Release of caspase9 from mitochondria during neuronal apoptosis and cerebral ischemia. Proceedings of the National Academy of Sciences, USA, 96: 5752-5757.

54. Wolter KG, Hsu YT, Smith CL, Nechushtan A, Xi XG \& Youle RJ (1997).
Movement of Bax from the cytosol to mitochondria during apoptosis. J ournal of Cell Biology, 139: 1281-1292.

55. Luo X, Budihardjo I, Zou H, Slaughter C \& Wang X (1998). Bid, a Bcl2 interacting protein, mediates cytochrome $\mathrm{c}$ release from mitochondria in response to activation of cell surface death receptors. Cell, 94: 481-490.

56. Garlid KD, Paucek P, Yarov-Yarovoy V, Murray HN, Darbenzio RB, D'Alonzo AJ ,
Lodge NJ , Smith MA \& Grover GJ (1997). Cardioprotective effect of diazoxide and its interaction with mitochondrial ATPsensitive $\mathrm{K}^{+}$channels. Possible mechanism of cardioprotection. Circulation Research, 81: 1072-1082.

57. Halestrap AP (1989). The regulation of the matrix volume of mammalian mitochondria in vivo and in vitro and its role in the control of mitochondrial metabolism. Biochimica et Biophysica Acta, 973: 355-382. 